\title{
Evaluating spatial coverage of data on the aboveground biomass in undisturbed forests in the Brazilian Amazon
}

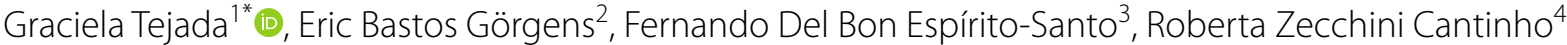
and Jean Pierre Ometto'

\begin{abstract}
Background: Brazilian Amazon forests contain a large stock of carbon that could be released into the atmosphere as a result of land use and cover change. To quantify the carbon stocks, Brazil has forest inventory plots from different sources, but they are unstandardized and not always available to the scientific community. Considering the Brazilian Amazon extension, the use of remote sensing, combined with forest inventory plots, is one of the best options to estimate forest aboveground biomass (AGB). Nevertheless, the combination of limited forest inventory data and different remote sensing products has resulted in significant differences in the spatial distribution of AGB estimates. This study evaluates the spatial coverage of AGB data (forest inventory plots, AGB maps and remote sensing products) in undisturbed forests in the Brazilian Amazon. Additionally, we analyze the interconnection between these data and AGB stakeholders producing the information. Specifically, we provide the first benchmark of the existing field plots in terms of their size, frequency, and spatial distribution.
\end{abstract}

Results: We synthesized the coverage of forest inventory plots, AGB maps and airborne light detection and ranging (LiDAR) transects of the Brazilian Amazon. Although several extensive forest inventories have been implemented, these AGB data cover a small fraction of this region (e.g., central Amazon remains largely uncovered). Although the use of new technology such as airborne LiDAR cover a significant extension of AGB surveys, these data and forest plots represent only $1 \%$ of the entire forest area of the Brazilian Amazon.

Conclusions: Considering that several institutions involved in forest inventories of the Brazilian Amazon have different goals, protocols, and time frames for forest surveys, forest inventory data of the Brazilian Amazon remain unstandardized. Research funding agencies have a very important role in establishing a clear sharing policy to make data free and open as well as in harmonizing the collection procedure. Nevertheless, the use of old and new forest inventory plots combined with airborne LiDAR data and satellite images will likely reduce the uncertainty of the AGB distribution of the Brazilian Amazon.

Keywords: Amazon, Tropical rain forest, Remote sensing, Carbon, Aboveground biomass, REDD+

\footnotetext{
${ }^{*}$ Correspondence: gracielatejadap@gmail.com

${ }^{1}$ Earth System Science Center (CCST), National Institute for Space Research (INPE), Av dos Astronautas 1758, São José dos Campos, SP 12227-010, Brazil

Full list of author information is available at the end of the article
} 


\section{Background}

The Amazon forest is a region of great interest for biodiversity, conservation, and ecosystem services. The Amazon holds a large stock of carbon in undisturbed forest. However, land use and land cover change have greatly impacted these forests [1-3]. The carbon stock of undisturbed forests is the starting point for quantifying the carbon emissions from deforestation $[4,5]$.

To quantify the carbon stocks at the national scale, Amazon countries have been using forest inventory plots to measure aboveground biomass (AGB) $[6,7]$. In the past few years, several studies have used high-resolution remote sensing data to estimate carbon stocks (e.g., Peru [8], Ecuador [9], Brazil [10-12]). AGB data estimates are also necessary for National Communications on greenhouse gases (GHG) and reduce emissions from deforestation and degradation (REDD+), both under the United Nations Framework Convention on Climate Change (UNFCCC) [13].

Brazil, which contains $60 \%$ of the Amazon region, has been using forest inventory plots to report its GHG inventories under the UNFCCC $[6,14,15]$. AGB quantification has many challenges, such as accessibility, long distances and high costs of field measurements in large areas, such as the Brazilian Amazon biome $\left(\sim 3,139,172 \mathrm{~km}^{2}\right.$ of undisturbed forest [16]) [17]. There are many forest inventory plots with AGB field measurements [4]. However, the collected AGB data are unstandardized and not always available to the scientific community to quantify forest carbon stocks.

Given the great extent and variability of forest structures in the tropics, remote sensing is one of the best tools for estimating the AGB $[18,19]$ of tropical forests. With the new remote sensing sensors and statistical methods, such as light detection and ranging (LiDAR) and random forest interpolation modeling, there has been a great advance in the AGB estimates [20,21] in the Brazilian Amazon. However, these efforts are still limited by the availability of data derived from field forest inventories $[17,22]$. The combination of field AGB data and different remote sensing products has resulted in significant differences in the spatial distribution of AGB estimates in produced AGB maps of the Brazilian Amazon [22, 23]. As a result, in estimating carbon emissions from deforestation, forest AGB remain the largest source of uncertainty in the tropics [5, 23].

This study evaluates the spatial coverage of AGB data in undisturbed forests in the Brazilian Amazon. We present the location and characteristics of forest inventory plots, AGB maps and remote sensing products. In addition, we analyzed the interconnection between these data and stakeholders generating the data (national forest inventories, ecological networks, projects and institutions). We identified the fraction of the undisturbed forest covered by forest inventories and evaluated the distribution of forest inventory plots across environmental factor maps (soil, topography, vegetation and climate).

\section{Methods}

This study focused on undisturbed forests of the Brazilian Amazon biome, an area of approximately 3,139,172 km², considering the 2014th deforestation mask provided by the Deforestation Monitoring Program (PRODES) data [16, 24] (Fig. 1).

The results derived from this study were cohesive derived from the following: [1] review and organization of the existing AGB data, i.e., forest inventory plot locations, airborne LiDAR transects and AGB maps across the Brazilian Amazon biome; [2] social network analysis (SNA) of the stakeholders working with AGB data; [3] coverage of forest inventory plots; and [4] quantification of the forest inventory plots across environmental factor maps (soil, topography, vegetation and climate).

We reviewed and organized the available AGB datasets of the Brazilian Amazon, e.g., past and ongoing forest inventory data, published AGB maps (and the field data used to produce them), airborne LiDAR transects and environmental factor maps. We used the following criteria to consider a forest inventory dataset: (i) the data are from undisturbed forests in the Amazon biome; (ii) the data must originate on more than one site in the Brazilian Amazon biome; and (iii) the forest inventory stakeholders have many interinstitutional collaborations. Several field datasets were available from personal contacts [2530]. All datasets from available AGB maps [6, 15, 18, 22, 31-35] and field plot locations were organized in a georeferenced dataset, and their institutional relations were placed in a Table as input to make an SNA (Additional file 1: Table S1).

We used an SNA to identify the relation between the stakeholders of field plots and AGB maps. The SNA consists of a set of actors (called nodes), a set of connections (called edges or links) between the actors, and an attribute that describes the type of each actor [36]. In our analyses, the actors were the stakeholders working with AGB data in the Brazilian Amazon biome. The attributes were the type of stakeholders, i.e., national or international universities, projects, main sites, main networks and institutions. The connections were the collaborations and links between the stakeholders (e.g., sharing field or remote sensing data) and were counted in pairs of actors, where one actor could have one or many connections (a detailed Table of the SNA is provided in Additional file 1: Table S1). The output is usually a figure that represents the connection strength between stakeholders; each stakeholder is a box, and the larger the boxes are (more 


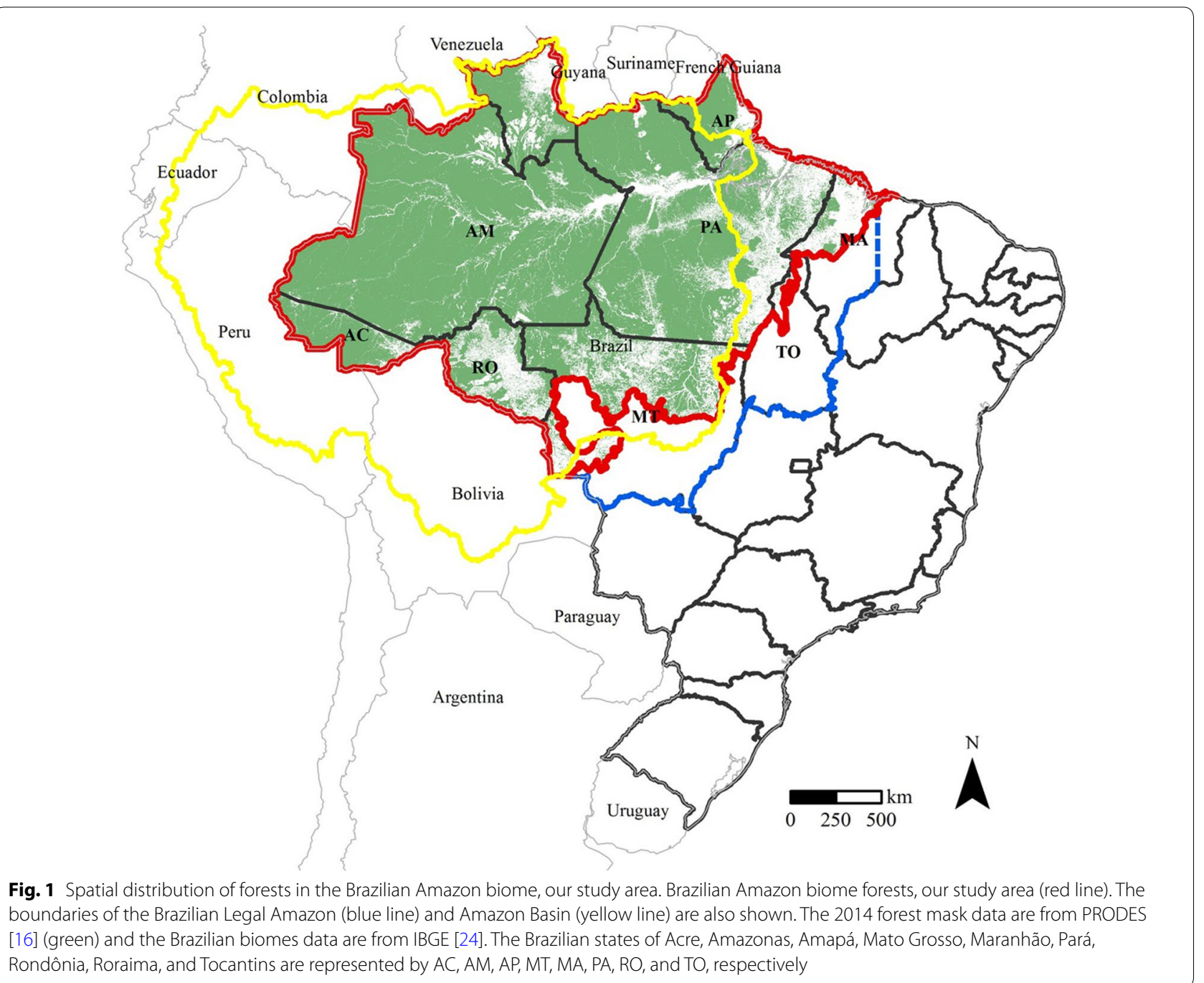

connections), the stronger the connections. The connections are represented by lines, and the attributes of the stakeholders are denoted by the color of the box.

To quantify the coverage of the AGB field plot data, we calculated the distance from the forest inventory plots in the Brazilian Amazon forest. To estimate the sampled area of the AGB plots, we considered the reported area of each forest inventory dataset. The location and area of LiDAR surveys were from two leading projects: the improving biomass estimation methods for the Amazon (EBA) [37] and sustainable landscapes (SL) [27].

We evaluated the representativeness of the forest inventory datasets by calculating the number of plots in each environmental factor map: soil with 42 classes [38], topography with 31 classes [39], vegetation with 28 classes [15] and climate expressed as dry months with 5 classes [40].

\section{Results}

\section{AGB datasets}

\section{Forest inventories}

We found at least ten stakeholders working on forest inventory plots of the Brazilian Amazon (Table 1). Each stakeholder sampled the forests using different protocols (i.e., objectives, plot sizes, area, spatial coverage, and sites). The largest forest inventory is from RadamBrasil ( $n=1682$ plots of 1 ha), which was sampled between 1973 and 1980. Six of the current AGB stakeholders of the Brazilian Amazon [the Amazon Forest Inventory Network (RAINFOR); Tropical Ecology, Assessment and Monitoring (TEAM); the Research Program for Biodiversity (PPBIO); SL; the Brazilian Forest Service; and the Tropical Ecosystems and Environmental Sciences Laboratory (TREES)] are still collecting forest inventory data in permanent plots (Fig. 2). 


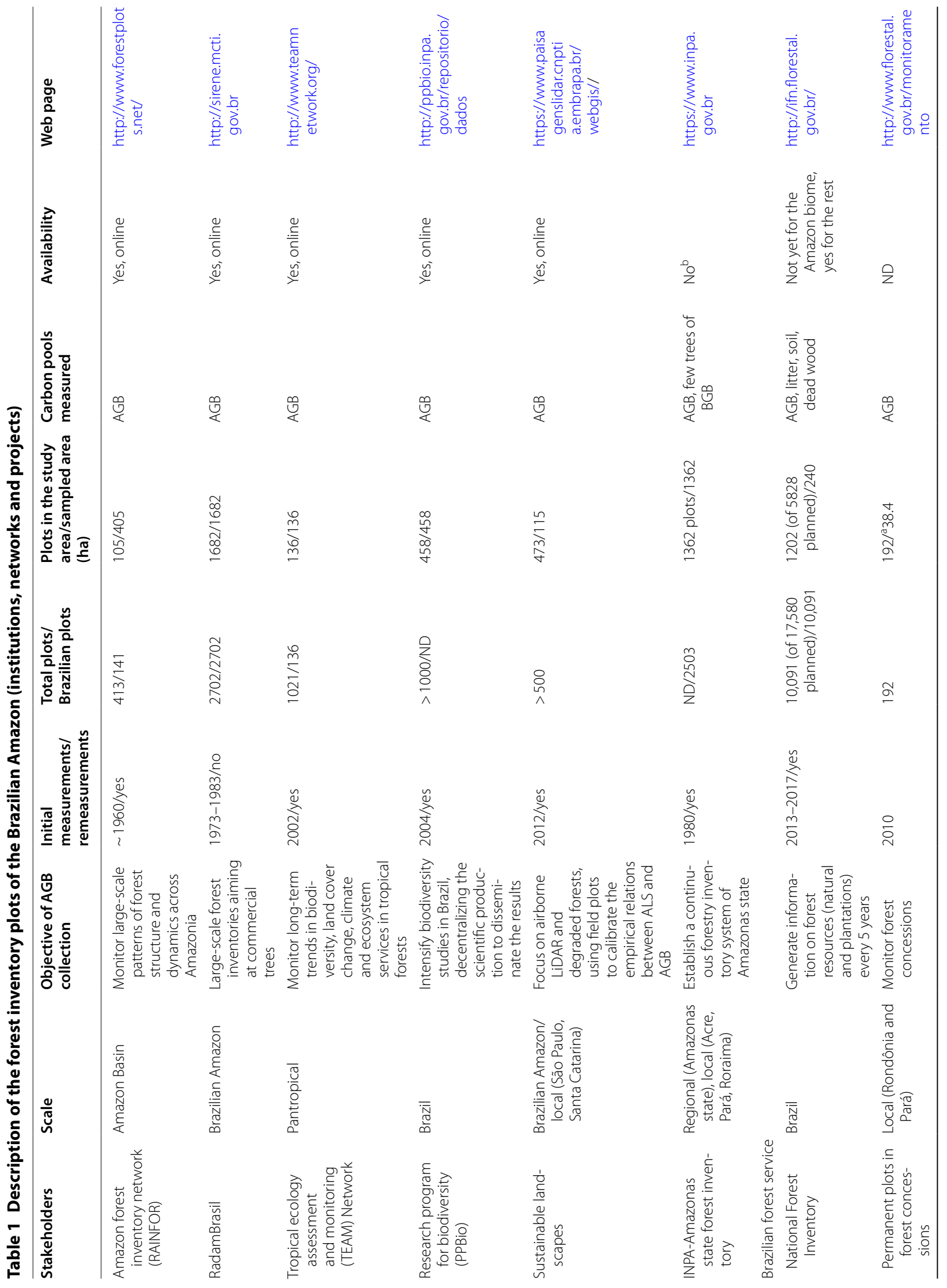




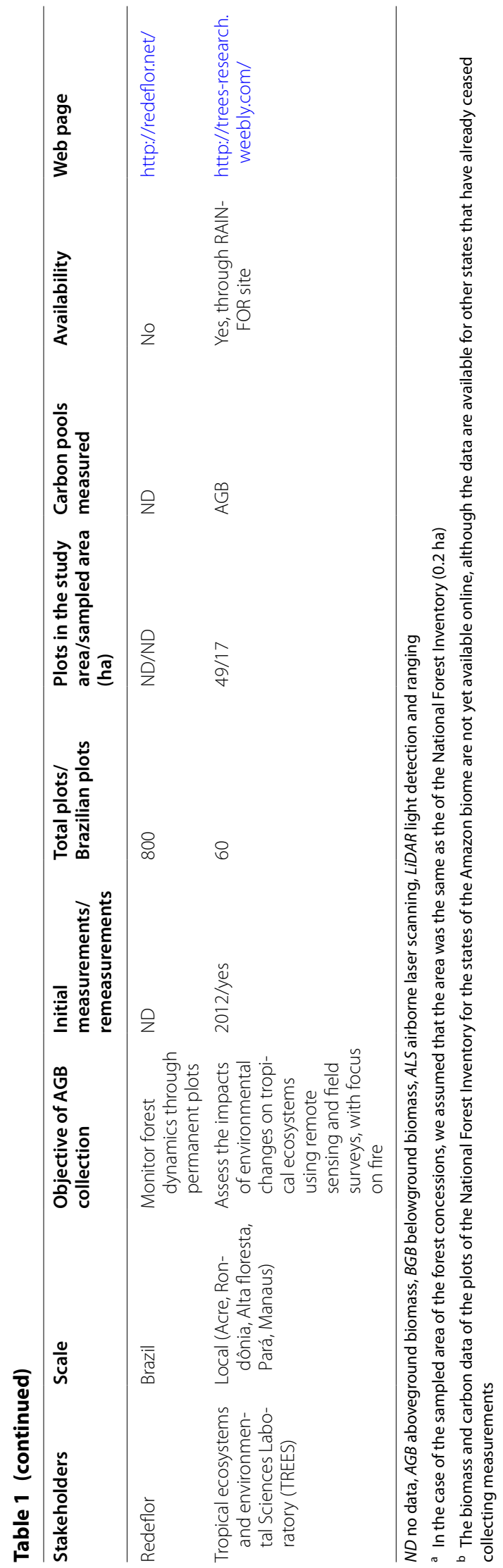



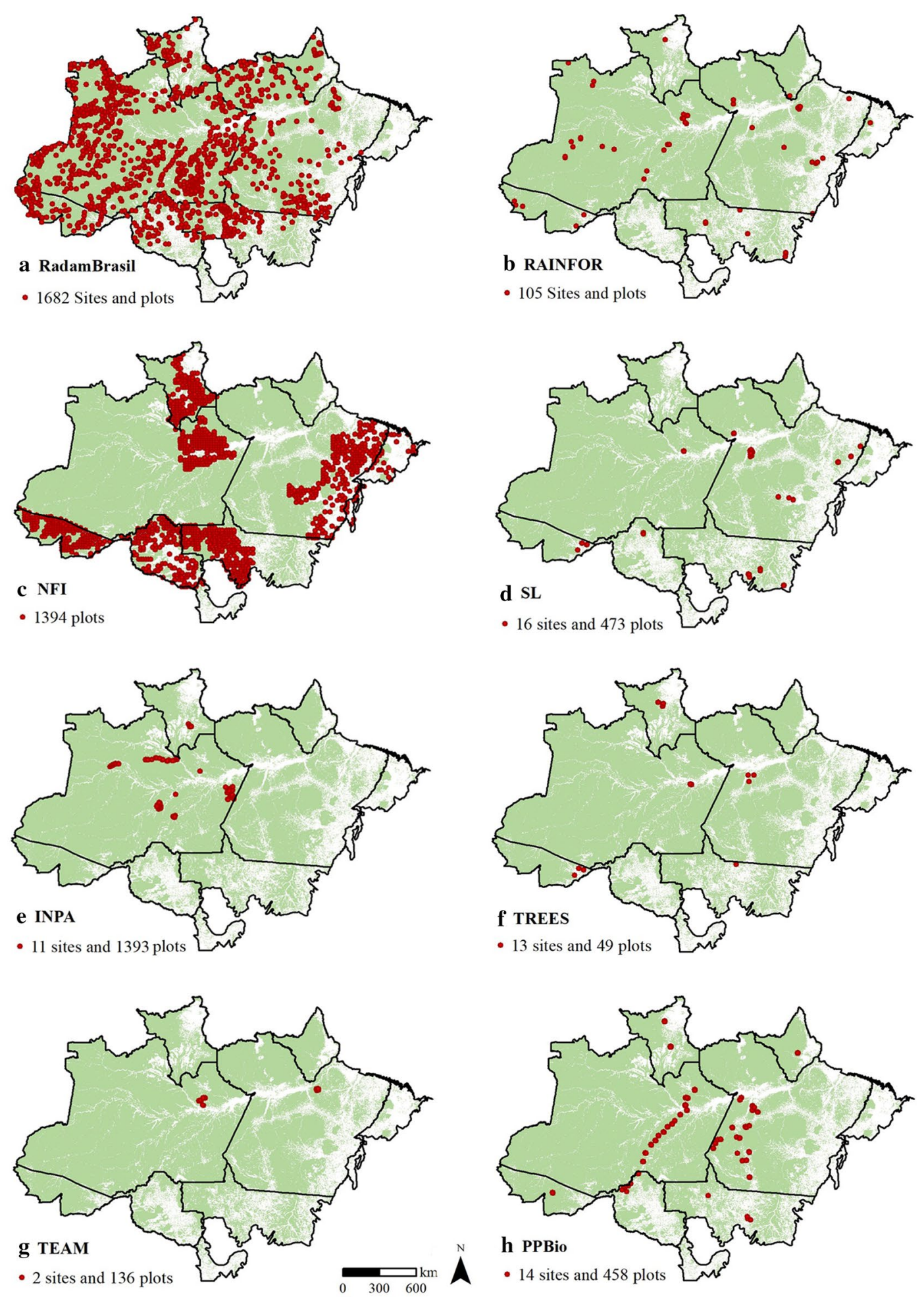

Fig. 2 Distribution of forest inventory plots in the Brazilian Amazon. a RadamBrasil [41]; b Amazon Forest Inventory Network (RAINFOR) [75]; C National Forest Inventory [26]; $\mathbf{d}$ sustainable landscapes project [27]; e National Institute of Amazon Research (INPA) (personal communication); $\mathbf{f}$ Tropical Ecosystems and Environmental Sciences Laboratory (TREES) [30]; g Tropical Ecology, Assessment and Monitoring Network (TEAM) [42]; and h Research Program for Biodiversity (PPBio) [45] 
The RadamBrasil project (1973-1983) recorded 2702 plots considering only commercial trees [41]. This dataset remains widely used due to its extensive coverage despite the date of measurement (almost 30 years ago) and absence of remeasurements. RadamBrasil plots were the field data input for the biomass maps of the second and third National Communications of Brazil to the UNFCCC [26, 27] and Nogueira et al. [30, 34] (Fig. 2a, c).

INPA's Forest Management Laboratory maintains an extensive plot network that includes the Continuous Forest Inventory (CFI) of the Amazonas state and contains more than 2500 AGB plots. Some of the plots are included in the RAINFOR, PPBio and TEAM [42].

The RAINFOR network monitors 413 AGB plots in the Amazon Basin, of which 105 are located in the Brazilian Amazon biome (Fig. 2b) [14, 15]. The TEAM network has two sites in the Brazilian Amazon, one in Manaus and the other in Caxiuanã, including a total of 136 AGB plots (Fig. 2g).

The TREES of the National Institute for Space Research (INPE) has 49 plots, of which 17 are used to monitor AGB (Fig. 2f) (the other plots are used to monitor fire impacts). The AGB plots are available through the RAINFOR website.

The SL project has airborne laser scanning (ALS) data and to calibrate remote sensing-based models, they monitor 473 AGB plots [32, 43]. Some of the AGB plots being monitored are part of other stakeholders (e.g., Embrapa Acre). All the recorded plots and the ALS dataset are recent, and the data are completely available on the Internet.

Another network is Redeflor, with 794 permanent plots around the Amazon [44]. The spatial locations of the plots are not available. The Brazilian Agricultural Research Corporation (Embrapa), universities, and some forest companies are part of the Redeflor forest inventory. Many of the Redeflor plots are included in the SL forest inventory.

INPA holds the international PPBio program. This program gathers many universities and institutes with the objective of decentralizing biodiversity studies and disseminating the results of biodiversity data. PPBio has approximately 460 1-ha plots in the Brazilian Amazon biome $[45,46]$.

The Brazilian Forest Service is in charge of the National Forest Inventory (NFI), for which extensive and systematic sampling is performed over a $5 \times 5 \mathrm{~km}$ grid. As of February 2019, 2280 (1202 in intact forest areas) out of 5828 planned sample plots had already been recorded in the Brazilian Amazon biome. Each plot is 0.2 ha. However, it is not clear how the NFI data will be published and distributed for the Amazon biome, although for the rest of the Brazilian biomes, AGB data are available online (Fig. 2c) [47]. The small size of the NFI plots brings abundant controversy regarding the best plot size for carbon assessments [48-50]. In addition to the NFI, the Brazilian Forest Service also has 192 permanent plots in forest areas under concession (Fig. 2c) [26].

\section{Remote sensing data}

The main remote sensing products of the vegetation index at the global level are Vegetation Tree Cover [11], GlobCover 2009 [51] and GLC 2000 [52]. These products are mainly based on optical datasets, such as those for Landsat and MODIS. The combination of Landsat and MODIS, active sensors from satellite platforms, such as Geoscience Laser Altimeter System (GLAS)-LiDAR, and forest inventory plots are used to generate AGB maps at a pantropical scale $[18,33]$, as shown in Table 2. Remote sensing technologies allow the estimation of forest biomass even over extensive and inaccessible areas. Airborne LiDAR and radar allow forest structure estimates in 3 dimensions [20], which is highly recommended for AGB inventories $[19,53]$.

Two projects are currently working with airborne LiDAR. The SL project has been running ALS surveys in different biomes (available at: https://www.paisagensl idar.cnptia.embrapa.br/webgis//) [27, 54]. The total area surveyed over the Amazon biome reached 44,764 ha in 2017 and is still increasing (Fig. 3a). The EBA (Improving Biomass Estimation Methods for the Amazon) project has 720 transects (and 130 transects overflown) with a total of 575,094 ha surveyed. Some of the transects have airborne hyperspectral data. EBA does not have AGB plots and is going to use plots from partners for calibration and validation [37]. SL and EBA are now focused on assessing the AGB of forest areas under different conditions (degraded, secondary, primary, etc.).

\section{Forest AGB maps}

The AGB maps for the Brazilian Amazon show differences in both AGB quantity and distribution (Table 2). For example, the National Communications AGB maps differ among themselves (Fig. $4 \mathrm{a}, \mathrm{g}$ ). Part of the difference is due to the spatialization technique. The Second Brazilian National Communication map presented the AGB estimates as a result of the aggregation of the AGB values per vegetation class and extrapolated considering RadamBrasil volume sheets. This approach leads to a gross quadrant-like AGB distribution [23, 55]. For the third National Communication map, a combination of extrapolation methods, equations and expansion factors were used, returning completely different AGB estimates [6]. Nogueira et al. [32, 34] produced an AGB map employing RadamBrasil field data and a stratification 
Table 2 Main characteristics of the Amazon forest AGB density maps

\begin{tabular}{|c|c|c|c|c|c|c|c|}
\hline Map & Scale & $\begin{array}{l}\text { Spatial } \\
\text { resolution }\end{array}$ & $\begin{array}{l}\text { Temporal scale } \\
\text { (years) }\end{array}$ & $\begin{array}{l}\text { Field forest } \\
\text { plots/source }\end{array}$ & $\begin{array}{l}\text { Study area } \\
\text { plots/sampled } \\
\text { area (ha) }\end{array}$ & $\begin{array}{l}\text { Remote sensing } \\
\text { products/other } \\
\text { inputs }\end{array}$ & Model \\
\hline Saatchi et al. [31] & Amazon Basin & $1 \mathrm{~km}$ & $2000-2004$ & $\begin{array}{c}\text { 544/many } \\
\text { sources }\end{array}$ & $\sim 361 / \sim 1633^{d}$ & $\begin{array}{l}\text { MODIS (NDVI, } \\
\text { LAI, \% tree } \\
\text { cover), JERS-1 } \\
\text { radar, SRTM/ } \\
\text { vegetation } \\
\text { map, climate } \\
\text { data (World- } \\
\text { Clim) }\end{array}$ & $\begin{array}{l}\text { Biomass clas- } \\
\text { sification } \\
\text { approach }\end{array}$ \\
\hline $\begin{array}{l}\text { Nogueira et al. } \\
\text { [32] }\end{array}$ & $\begin{array}{l}\text { Brazilian Ama- } \\
\text { zon }\end{array}$ & $\begin{array}{l}1 \text { km (landscape } \\
\text { level) }\end{array}$ & Only 1976 & $\begin{array}{l}\text { 2879/Radam- } \\
\text { Brasil and } \\
\text { literature }\end{array}$ & 2879/2879 & $\begin{array}{c}\text { No/vegetation } \\
\text { map [40] }\end{array}$ & None \\
\hline MCT [15] & $\begin{array}{l}\text { Brazilian Ama- } \\
\text { zon }\end{array}$ & $\begin{array}{l}1 \text { km (landscape } \\
\text { level) }\end{array}$ & $1973-1983^{a}$ & $\begin{array}{l}\text { 1710/Radam- } \\
\text { Brasil and } \\
\text { literature }\end{array}$ & $1682 / 1682$ & $\begin{array}{l}\text { No/vegetation } \\
\text { [19], soils [41] }\end{array}$ & None \\
\hline Saatchi et al. [18] & Pantropical & $1 \mathrm{~km}$ & 2000 & $\begin{array}{l}4079^{b} \text { (493 for } \\
\text { calibration)/ } \\
\text { many sources }\end{array}$ & $\sim 707 / \sim 1770^{d}$ & $\begin{array}{l}\text { MODIS (NDVI, } \\
\text { LAl, \% tree } \\
\text { cover), LiDAR } \\
\text { from GLAS/ } \\
\text { forest height } \\
\text { map }\end{array}$ & MaxEnt \\
\hline Baccini et al. [33] & Pantropical & $500 \mathrm{~m}$ & 2007-2008 & $283^{\mathrm{b}} /$ measured & No data & $\begin{array}{l}\text { MODIS, LiDAR } \\
\text { from GLAS, } \\
\text { SRTM }\end{array}$ & RandomForest \\
\hline $\begin{array}{l}\text { Mitchard et al. } \\
\text { [22] }\end{array}$ & Amazon Basin & $500 \mathrm{~m}$ & $1960-2013^{a}$ & $\begin{array}{c}\text { 413/RAINFOR } \\
\text { and TEAM }\end{array}$ & $105 / 405$ & $\begin{array}{l}\text { No/regional } \\
\text { map based } \\
\text { on geography } \\
\text { and substrate } \\
\text { origin }\end{array}$ & $\begin{array}{l}\text { Kriging, inverse } \\
\text { distance kernel }\end{array}$ \\
\hline $\begin{array}{l}\text { Nogueira et al. } \\
\text { [34] }\end{array}$ & $\begin{array}{l}\text { Brazilian Ama- } \\
\text { zon }\end{array}$ & $\begin{array}{l}1 \text { km (landscape } \\
\text { level) }\end{array}$ & $1970^{a}$ & $\begin{array}{c}2317^{c} / \text { Radam- } \\
\text { Brasil and } \\
\text { literature }\end{array}$ & 2373/2317 & $\begin{array}{c}\text { No/vegetation } \\
\text { map [40] }\end{array}$ & None \\
\hline $\begin{array}{l}\text { Avitabile et al. } \\
\text { [35] }\end{array}$ & Pantropical & $1 \mathrm{~km}$ & $2000-2013^{a}$ & $\begin{array}{c}\text { 648/RAINFOR, } \\
\text { TEAM and } \\
\text { sustainable } \\
\text { landscapes }\end{array}$ & 500/No data & $\begin{array}{l}\text { No/high-resolu- } \\
\text { tion AGB maps }\end{array}$ & Fusion model \\
\hline MCT [6] & $\begin{array}{l}\text { Brazilian Ama- } \\
\text { zon }\end{array}$ & $\begin{array}{l}1 \text { km (landscape } \\
\text { level) }\end{array}$ & $1973-1983^{a}$ & $\begin{array}{l}1682 \text { plots/ } \\
\text { RadamBrasil }\end{array}$ & $1682 / 1682$ & $\begin{array}{l}\text { No/vegetation } \\
\text { [19], soils [41] }\end{array}$ & $\begin{array}{l}\text { Inverse distance } \\
\text { weighting }\end{array}$ \\
\hline
\end{tabular}

RAINFOR Amazon forest inventory network, TEAM tropical ecology, assessment and monitoring, MODIS moderate resolution imaging spectroradiometer, NDVI normalized difference vegetation index, LA/ leaf area index, GLAS geoscience laser altimeter system, LiDAR light detection and ranging, SRTM shuttle radar topography mission, JERS-1 Japanese earth resources satellite 1

a AGB field measurements

b We did not have access to the locations of the plots

c In the case of the RadamBrasil plots, we had the locations of only 1682 plots

d The total area of the plots was estimated because the plot had different sizes

approach aggregating AGB by vegetation map classes (Fig. 4c, Table 2).

At the pantropical scale, the map of Saatchi et al. [18] used a combination of global forest height, remote sensing, and field data (Fig. 4b, Table 2). It was employed as the basis for determining carbon emissions from the deforestation map of Harris et al. [56]. Another map constructed at the pantropical scale is the carbon density map of Baccini et al. [33] (Table 2 and Fig. 4c), which was based on multispectral surface reflectance data and established field plots colocated with satellite LiDAR footprints. Mitchard et al. [22] (Fig. 4d) produced an AGB map from a kriging extrapolation of RAINFOR forest inventory plots. Avitabile et al. [35] (Fig. 4f) combined 2 maps [18, 33] using a data fusion approach that included field data from RAINFOR and the SL project to produce a new AGB map (see Table 1). 


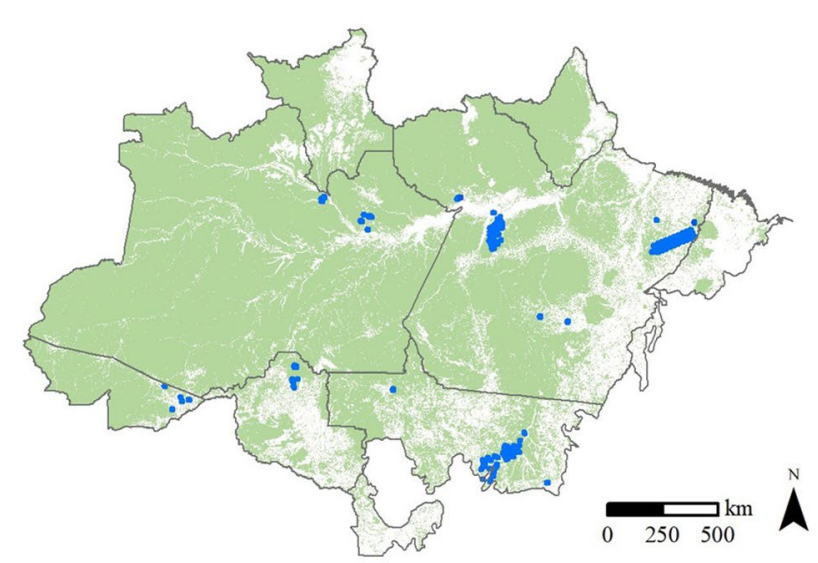

a Sustainable Landscapes Brazil Project (SLB)

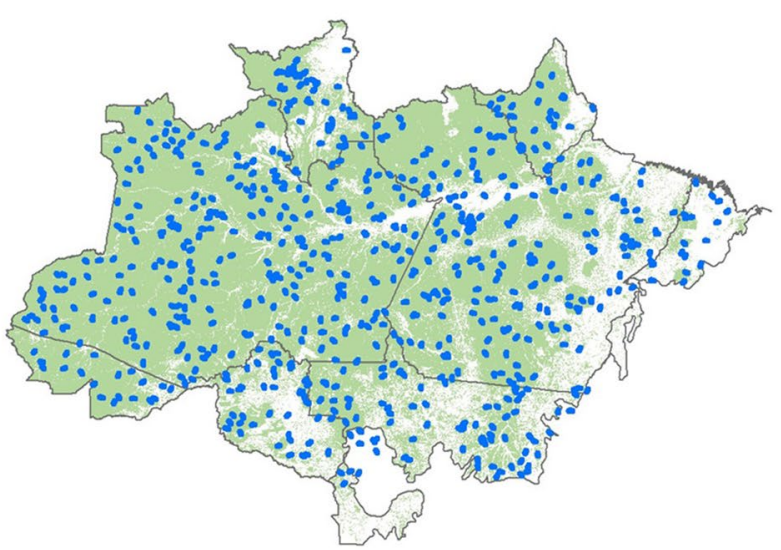

b Amazon Biomass Estimation Project (EBA)

1 720 LiDAR transects and 575,094 ha

Fig. 3 Distribution of the airborne LiDAR data in the Brazilian Amazon. a Sustainable landscapes [54]; b Amazon Biomass Estimation subproject 7 [37]

\section{Environmental factors}

Environmental factors, such as climate, soil and topography, have been used for a wide range of AGB estimates in the Brazilian Amazon [31, 57, 58]. Our compilation of the environmental factors showed 13 layers available at the Amazon scale (Table 3).

The representation of AGB is strongly associated with precipitation (both its amount and seasonality), which ranges from 80 to $300 \mathrm{~mm} / \mathrm{month}$. Additionally, the gradient in nutrient availability (mainly phosphorus) throughout the Amazon is also associated with AGB [59]. Vegetation physiognomy maps [60] have been used as inputs for many biomass maps $[6,14,15,34,61]$.

\section{AGB stakeholders}

The SNA results reveal the interrelationship between the different stakeholders working with AGB data. Stronger relationships are represented by the size of the box, and the more connections between the stakeholders, the larger the box size (Fig. 5); a detailed number of connections is provided in Additional file 1: Table S1.

The most connected stakeholders are the networks. PPBio has 9\% of the total connections, followed by RAINFOR with $8 \%$, both of which gather several institutions, universities, sites, projects and other networks. The SL project follows with 7\% gathering national and international institutions, universities and networks (Fig. 5). The National and the Amazon state forest inventories also have many connections, $5 \%$ and $4 \%$, respectively, although they are not connected to each other.
The large-scale biosphere-atmosphere experiment in Amazonia (LBA), known for its flux towers and AGB plots, is a project with many connections (4\%) and has been collecting data since 1999. Institutions such as the INPA, INPE (holding the TREES laboratory and EBA project) and Embrapa are also visible stakeholders in Fig. 5, with more than 3\% of the connections. Wellknown sites with AGB plots are the ZF2 in Manaus (3\%), Tapajós in Santarem (2\%), and Caxiuanã in Belem (2\%), which are shared by many networks, institutions and projects.

\section{Coverage of the forest inventory data}

Taking into account the plots gathered by the forest inventory stakeholders, we found at least 5351 plots spread out over the Brazilian Amazon forest (Table 4). Among the plots, $26 \%$ are measured and maintained by INPA, with $26 \%$ of the current plots being attributed to the NFI and $25 \%$ to RadamBrasil, followed by SL (9\%) and PPBio (9\%). Other initiatives are responsible for less than $5 \%$. We observed that the forest inventory plots area cover only $0.0013 \%$ of the total forest area of the Brazilian Amazon.

The distance from the current plots (considering all forest inventory plots) is shown in Fig. 6a. The area of the Brazilian Amazon biome with more than $50 \mathrm{~km}$ from the nearest plot is $708,600 \mathrm{~km}^{2}$, representing $17 \%$ of the total area. In Fig. 6b, we show the distribution of the AGB dataset without RadamBrasil (for being old measurements), indicating a large increase $\left(2,246,500 \mathrm{~km}^{2}\right)$ in the places with no plot data, which represent $42 \%$ of the total 


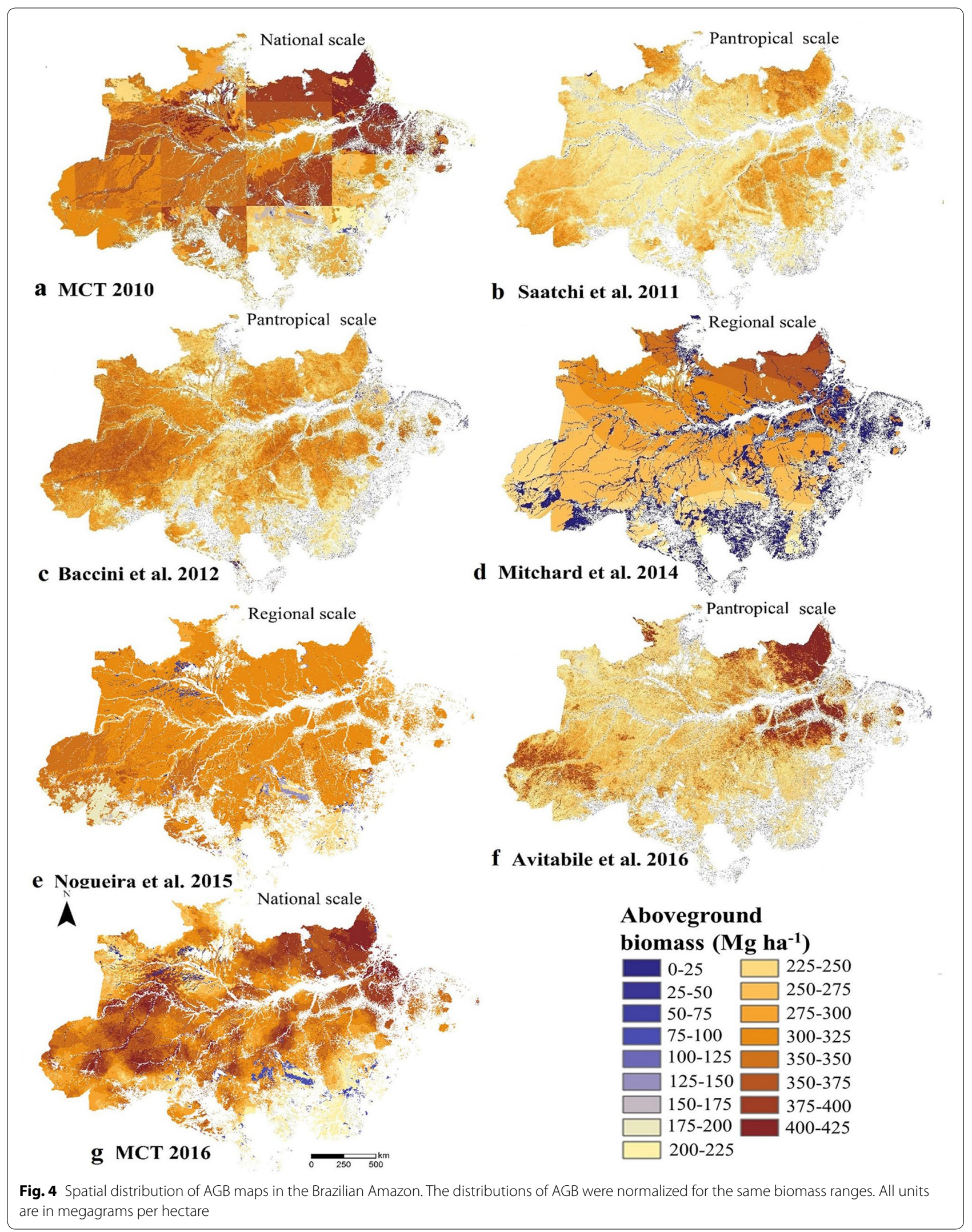


Table 3 Environmental factor maps in the Brazilian Amazon

\begin{tabular}{|c|c|c|c|c|c|}
\hline Environmental factor & Maps & Description & Coverage & $\begin{array}{l}\text { Spatial } \\
\text { resolution } \\
\text { scale }\end{array}$ & Download site \\
\hline \multirow[t]{3}{*}{ Vegetation } & Vegetation map [62] & $\begin{array}{l}\text { Based on the RadamBrasil } \\
\text { map, with the land-use } \\
\text { classes updated by the } \\
\text { SIVAM project }\end{array}$ & National & $1: 250,000$ & $\begin{array}{l}\text { http://mapas.mma.gov.br/i3geo/ } \\
\text { datadownload.htm }\end{array}$ \\
\hline & IBGE vegetation map [63] & $\begin{array}{l}\text { Part of the wall maps of IBGE, } \\
\text { based on RadamBrasil map } \\
\text { with the land-use classes } \\
\text { updated by the SIVAM } \\
\text { project }\end{array}$ & National & $1: 5,000,000$ & $\begin{array}{l}\mathrm{ftp}: / / g e o f t p . i b g e . g o v . b r / i n f o r \\
\text { macoes_ambientais/ }\end{array}$ \\
\hline & $\begin{array}{l}\text { Vegetation physiognomies of } \\
\text { Brazil [15] }\end{array}$ & $\begin{array}{l}\text { Map used in the National } \\
\text { Communications grouping } \\
\text { of the transition classes of } \\
\text { the IBGE vegetation map [63] }\end{array}$ & Regional & $1: 250,000$ & http://sirene.mcti.gov.br \\
\hline \multirow[t]{4}{*}{ Soils } & Soil map of Brazil [64] & $\begin{array}{l}\text { The soil map used in the new } \\
\text { Brazilian system of soil clas- } \\
\text { sification of Embrapa and } \\
\text { published by IBGE }\end{array}$ & National & $1: 5,000,000$ & $\begin{array}{l}\text { http://mapas.mma.gov.br/i3geo/ } \\
\text { datadownload.htm }\end{array}$ \\
\hline & Soils of legal Amazon [65] & $\begin{array}{l}\text { This is an adaptation of the } \\
\text { Embrapa/IBGE } 2001 \text { soil } \\
\text { map [64] }\end{array}$ & National & $1: 250,000$ & $\begin{array}{l}\text { http://mapas.mma.gov.br/i3geo/ } \\
\text { datadownload.htm }\end{array}$ \\
\hline & Soils [38] & Soil carbon stocks & National & - & - \\
\hline & Soil map [66] & $\begin{array}{l}\text { Soil maps with particular refer- } \\
\text { ence to RAINFOR sites. Basin } \\
\text { wide distributions of soils } \\
\text { under forest vegetation }\end{array}$ & Regional & $1: 5,000,000$ & - \\
\hline \multirow[t]{2}{*}{ Climate } & WorldClim global climate data & $\begin{array}{l}\text { WorldClim, uses meteorologi- } \\
\text { cal field station observations } \\
\text { from } 1950 \text { to } 2000\end{array}$ & Global & - & www.worldclim.org \\
\hline & Climate map of Brazil [40] & $\begin{array}{l}\text { Thematic map of Brazil, data } \\
\text { from } 1978 \text { with adaptations } \\
\text { in } 2002\end{array}$ & National & $1: 5,000,000$ & $\begin{array}{l}\text { http://www.ibge.gov.br/engli } \\
\text { sh/geociencias/default_prod. } \\
\text { shtm }\end{array}$ \\
\hline \multirow[t]{2}{*}{ Elevation } & SRTM 90 m (NASA, 2000) & SRTM of $90 \mathrm{~m}$ resolution & Global & $90 \mathrm{~m}$ & $\begin{array}{l}\text { http://www2.jpl.nasa.gov/srtm/ } \\
\text { cbanddataproducts.html }\end{array}$ \\
\hline & SRTM 30 m (TOPODATA) & SRTM of 30 m resolution & Global & $30 \mathrm{~m}$ & $\begin{array}{l}\text { http://www2.jpl.nasa.gov/srtm/ } \\
\text { cbanddataproducts.html }\end{array}$ \\
\hline \multirow[t]{2}{*}{ Topography } & Relief map 2002 [39] & $\begin{array}{l}\text { Relief map } 2002 \text { (Compar- } \\
\text { timentos do relevo do } \\
\text { Brasil-2002) }\end{array}$ & National & $1: 250,000$ & $\begin{array}{l}\text { http://mapas.mma.gov.br/i3geo/ } \\
\text { datadownload.htm }\end{array}$ \\
\hline & Relief units map of Brazil [67] & $\begin{array}{l}\text { Thematic map, based on the } \\
\text { RadamBrasil Project and } \\
\text { improved by the SIVAM } \\
\text { project }\end{array}$ & National & $1: 5,000,000$ & $\begin{array}{l}\text { ftp://geoftp.ibge.gov.br/infor } \\
\text { macoes_ambientais/geomo } \\
\text { rfologia/vetores/brasil/ }\end{array}$ \\
\hline
\end{tabular}

area. Figure 6c presents the situation without the RadamBrasil, NFI (not yet available) and INPA (not available) plots, showing that more than $80 \%\left(3,409,750 \mathrm{~km}^{2}\right)$ of the Brazilian Amazon biome has no plot representativeness.

\section{AGB data and environmental factors}

Crossing forest inventory plots and environmental factor maps, such as soil, vegetation, topography and precipitation (represented as dry months), few classes account for most of the plots of the Brazilian Amazon biome (Fig. 7).
However, the represented classes usually account for the largest area.

Analyzing the vegetation types, lowland dense humid forests represent $28 \%$ of the area and comprise $44 \%$ of the plots; submontane dense humid forest represents $26 \%$, and of the area and $17 \%$ of the plots; open submontane humid forest represents $14 \%$ of the area and $15 \%$ of the plots; and open ombrophilous lowland forest represents $12 \%$ of the area and $8 \%$ of the plots (Fig. $7 \mathrm{a}$ ).

Only 4 of the 42 soil classes exhibit considerable numbers of plots. Low-activity clay non-latosols with dense 


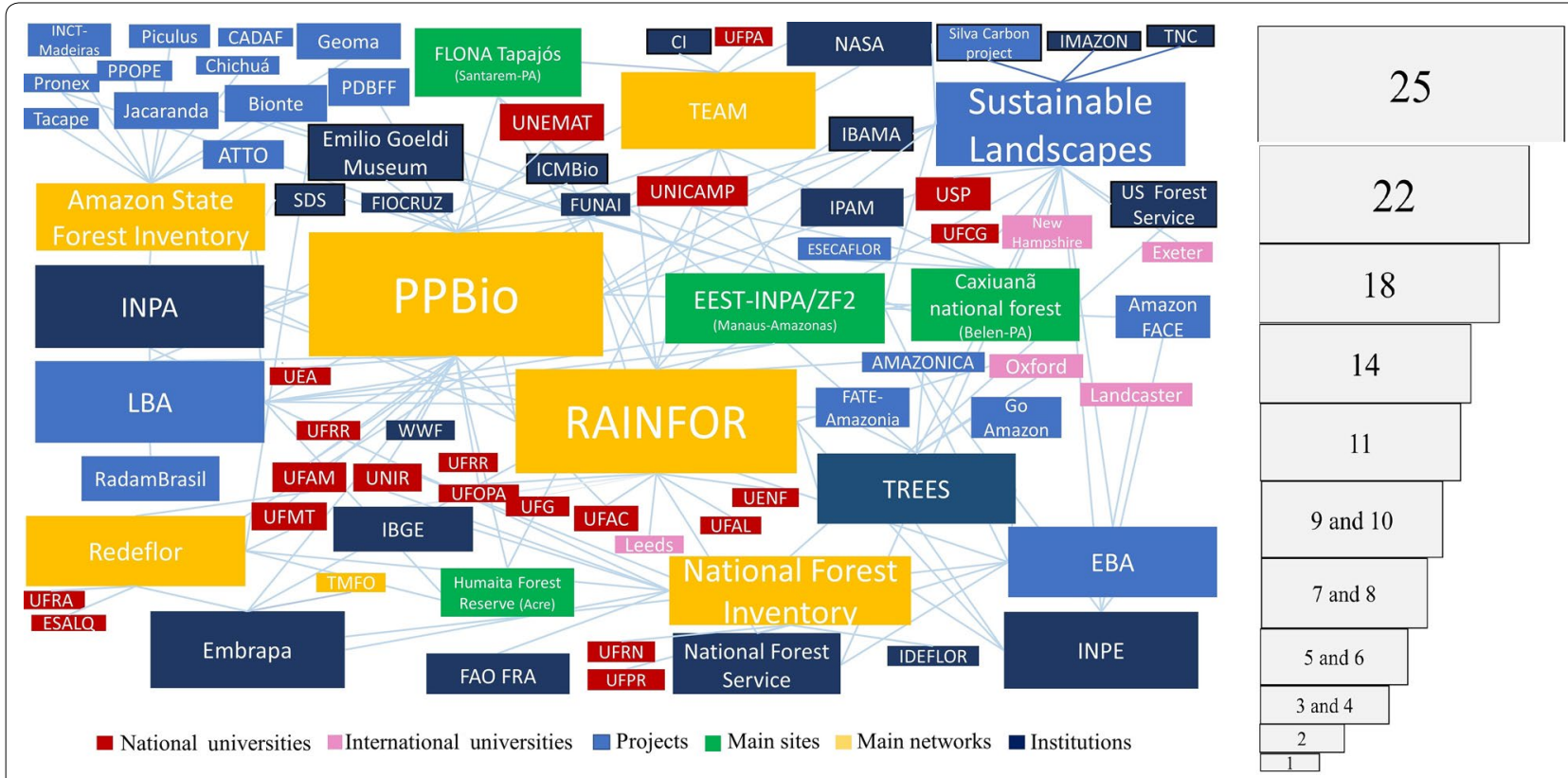

Fig. 5 Connections between stakeholders of forest inventory plots of the Brazilian Amazon. Stakeholders include networks, projects, institutions, universities and sites. The size of each box represents the number of connections between the stakeholders. A Table of the SNA is provided in Additional file 1: Table S1 and contains detailed information regarding the connections and acronyms

Amazon forest (26\% of the area) comprises $21 \%$ of the plots; low-activity clay latosols with dense Amazon forest (21\% of the area) comprises $27 \%$ of the plots; lowactivity clay non-latosols with open Amazon forest (15\% of the area) has $10 \%$ of the plots; and wet soils with dense Amazon forest ( $9 \%$ of the area) has $15 \%$ of the plots. The remaining plots are spread out over the other 38 soil classes (Fig. 7b).

The classes for 1 to 2 dry months and 3 dry months represent the largest area, 31 and $34 \%$, and comprise 29 and $34 \%$ of the plots, respectively. The other two classes with the largest amounts of rain represent 20 and $1 \%$ of the area, with each representing $15 \%$ of the plots (Fig. 7c). From a total of 31 topography classes, only 4 represent $65 \%$ of the plots. However, these 3 classes cover more than $70 \%$ of the Amazon (Fig. 7d).

\section{Discussion}

The process of synthesizing and organizing the data of forest inventories, airborne LiDAR transects and AGB maps, is not trivial. Scientific literature usually mentions the location of the AGB data, but not always the project, the institution or network to which data belong. The social network analysis (SNA) was fundamental to organize and understand the AGB data and the relations between the stakeholders working in Brazilian Amazon forests.
The AGB data coverage shows that there is a lack of in situ information for large regions of the Amazon (Fig. 6). Excluding the RadamBrasil plots, by assuming that they are outdated (1973-1983), the area with no field data increases substantially. In this context, the NFI is a particularly important initiative. Depending on whether these data become available, the number of AGB plots will increase significantly, reaching 7000 systematically distributed plots in the Amazon biome, which will be remeasured regularly for long-term biomass monitoring (although the plot size is only $0.2 \mathrm{ha}$ ).

Gaining access to the data remains the largest challenge because most of these data are not currently publicly available (Fig. 6). INPA and NFI plots represent more than $50 \%$ of the total plots (Table 4). The problem regarding AGB data coverage will not be completely solved by implementing more plots if the information remains unavailable.

A lack of transparency or open data policies makes the analysis of uncertainty very difficult [68]. This analysis is required for monitoring and measurement, reporting and verification (MRV) in the context of the REDD+ national programs [7]. A consolidated and open-access AGB database is urgently needed to improve future National Communications and biomass mapping. In this context, funders play an important role in the AGB data distribution policy, requiring that the products of supported projects are free and openly available [7]. This could improve 


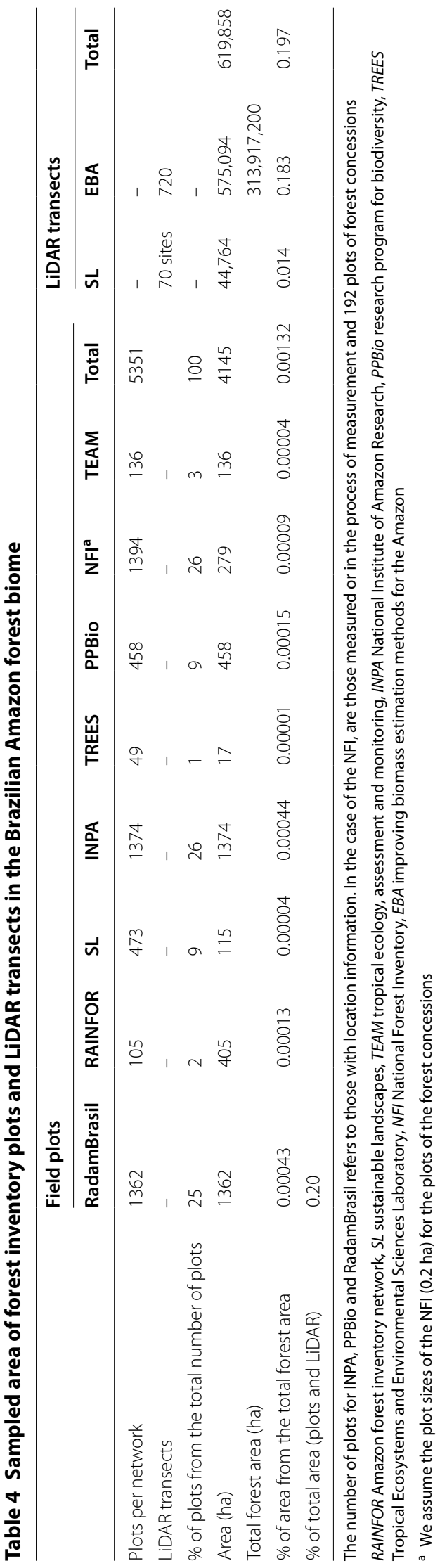



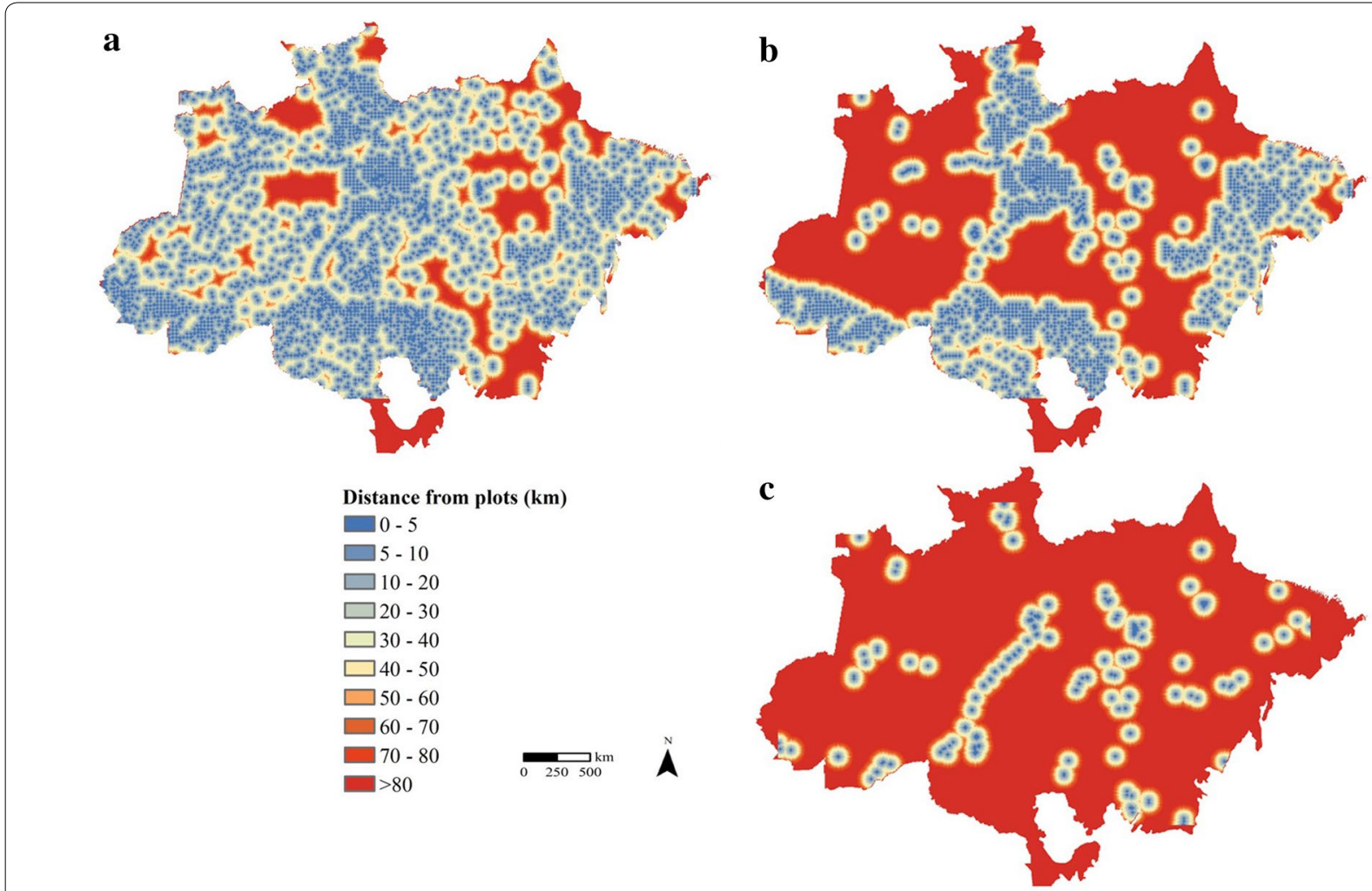

Fig. 6 Distances from forest inventory plots in the Brazilian Amazon. a Considering all forest inventory plots; $\mathbf{b}$ excluding plots from RadamBrasil; and $\mathbf{c}$ excluding the data from RadamBrasil, INPA and the National Forest Inventory plots

the uncertainty related to AGB data because the AGB data users' feedback will help improve the datasets (e.g., the MapBiomas initiative [69]).

Local and regional efforts, such as PPBio, RAINFOR and SL, which gather data from numerous projects and networks (i.e., INPA, RAINFOR and TEAM) and make it public, are essential for monitoring AGB changes over time and the impacts of anthropogenic and climate change on carbon storage in the Amazon forest. These three stakeholders, which provide AGB data to the public, are the most connected in the SNA (Fig. 5 and Additional file 1: Table S1), showing the importance of improving collaborations and developing a consistent data sharing policy.

The SNA can be considered an initial attempt to map the AGB stakeholders connections (Fig. 5). The detected links between stakeholders do not necessarily imply synergy between them and, even more, do not imply resource optimization. Improving the synergies detection and analysis are fundamental for improving collaboration and enhancing financial aid. Federal public universities and national research institutes are fundamental players in the current network framework for generating AGB data. The communication between those groups should be improved, the data collection should be standardized, and, most importantly, the data distribution policy should be nationally established and linked to funding access.

The small coverage of the field plots $(0.0013 \%)$ reveals the necessity of including and promoting national remote sensing approaches. Considering the ALS surveys, the sampled area covered increases to $0.197 \%$ of the Brazilian Amazon (0.014\% for SL and 0.183\% for EBA) (Table 4).

At the scale of the Brazilian Amazon, ASL data are improving forest mapping (Fig. 3), mainly through datasets collected by the SL and EBA projects [37, 54]. The goal of the EBA project with all the ALS data is to improve the AGB estimation of the Brazilian Amazon [37]. At a global scale, the Earth Explorer Biomass initiative [70] and the Global Ecosystem Dynamics Initiative (GEDI) mission promise to bring great contributions in the next 5 years [17]. Moreover, mapping environmental factors that influence the AGB estimation and distribution is highly recommended.

Despite the challenges at the field level, many AGB maps are available, although significant differences exist between the approaches used to generate those maps (Table 5). The reason for the observed differences in the 


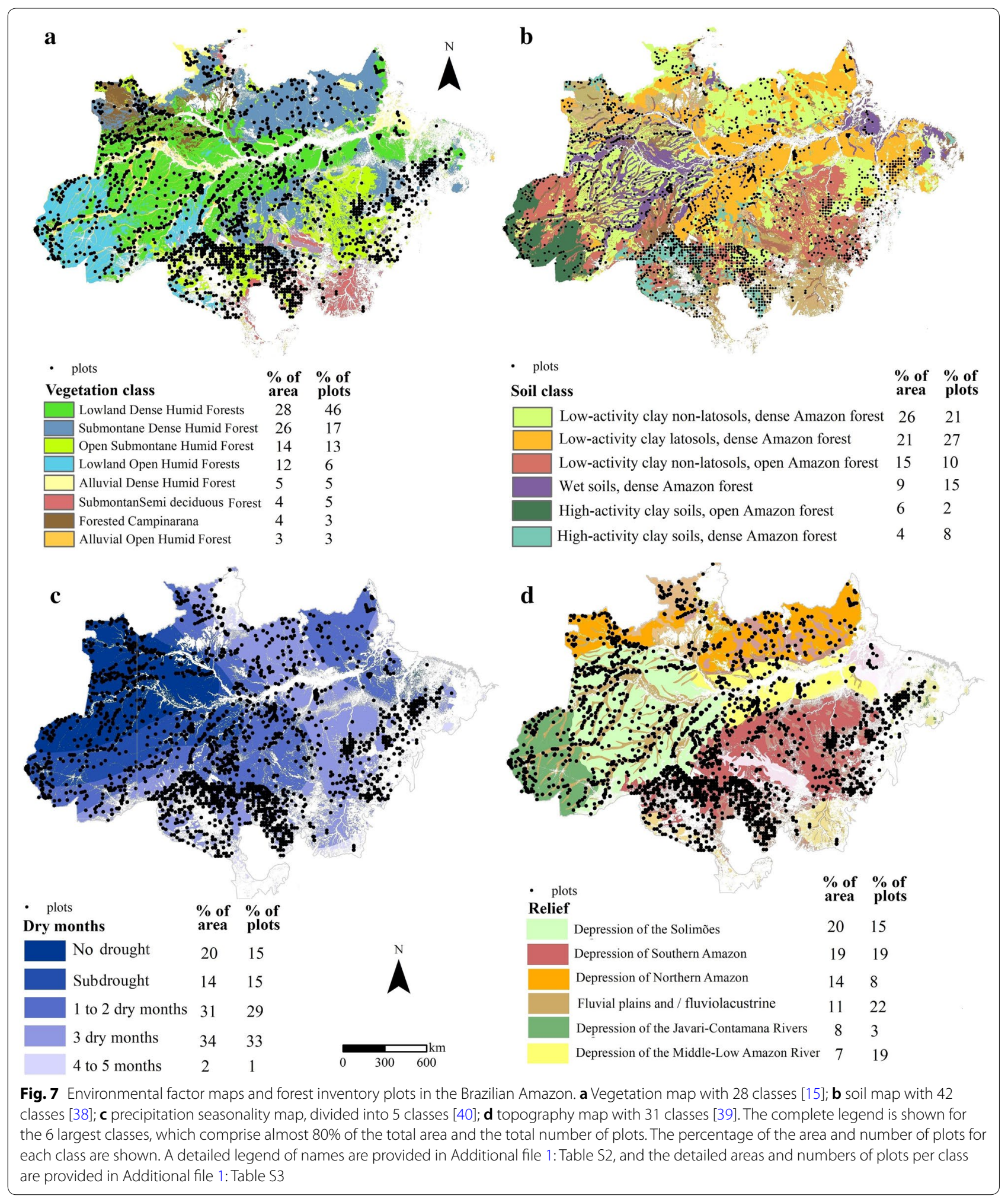


Table 5 Approaches to mapping AGB of the Brazilian Amazon

\begin{tabular}{lll}
\hline AGB maps & $\begin{array}{l}\text { Approaches } \\
\text { to mapping carbon } \\
\text { stocks }\end{array}$ & General description \\
\hline $\begin{array}{l}\text { Nogueira et al. [34] } \\
\text { MCT 2010 [15] }\end{array}$ & Stratify and multiply & $\begin{array}{c}\text { Assign an average AGB } \\
\text { value to land cover/ } \\
\text { vegetation type map }\end{array}$ \\
$\begin{array}{l}\text { Mitchard et al. [22] } \\
\text { MCT [6] }\end{array}$ & $\begin{array}{l}\text { Empirical models where } \\
\text { Saatchi et al. [18] }\end{array}$ & Direct remote sensing \\
Baccini et al. [33] & & $\begin{array}{l}\text { are calibrated to field } \\
\text { estimates }\end{array}$ \\
Avitabile et al. [35] & & rata
\end{tabular}

The general approaches to mapping AGB are described according to Goetz et al. [72]

quantity and distribution of AGB estimates (Fig. 4) is that each AGB map relies on different field data and different techniques for upscaling the AGB information to the map level [19, 23, 71].

It is difficult to define AGB strata derived from environmental factors, such as vegetation, soil, precipitation and topography data. The interrelationships between these factors are not completely understood at the regional scale $[18,31,73]$. A better comprehension is urgently required to stratify and improve AGB estimations [74]. The implications of not considering stratification, based on either vegetation types, slope aspects, or the combination of both, for AGB estimations are the cost, time and work of establishing forest inventory plots and the high cost of acquiring airborne LiDAR transects due to the large area of the Brazilian Amazon biome. Thus far, there has been no consensus on AGB stratification in the Brazilian Amazon biome, which is why the NFI and the EBA project have opted for a systematic sampling instead of a stratified one. Our estimation of the number of AGB plots for each environmental factor map shows that the maps have many strata with a few large classes where most plots are located. The NFI, EBA and SL AGB data could be used to analyze which environmental factor map (or which strata) better represents AGB. Moreover, variance analyses of the AGB data (of maps and available plots) within each environmental factor map class should be considered in future studies.

\section{Conclusions}

Several AGB stakeholders involved in forest inventories have different goals, protocols, and time frames for forest surveys; forest inventory data of the Brazilian Amazon remain unstandardized. Although some long-term relationships between the stakeholders exist, there is no standard protocol for distributing AGB data to ensure clarity, understandability and comparability. Research funding agencies have a very important role in establishing a clear sharing policy to make data free and open as well as in harmonizing the collection procedure. Such measures could have positive implications for National Communications, carbon mapping and REED+ activities.

The forest inventory plots coverage sampled a small fraction of the Brazilian Amazon forest carbon stocks. The NFI and airborne LiDAR data play an important role in filling gaps in the existing AGB data and updating the national scale information currently filled by the RadamBrasil dataset. Additionally, remote sensing data are crucial for covering continental areas, such as the Brazilian Amazon. It is essential to generate quality AGB data to monitor forest carbon and to understand the resilience of tropical forests facing deforestation, degradation, and climate change.

\section{Supplementary information}

Supplementary information accompanies this paper at https://doi. org/10.1186/s13021-019-0126-8.

Additional file 1: Table S1. Table of social network analysis connections and acronyms from Fig. 5. Table S2: Detailed legend of Fig. 7. Table S3: Table of AGB plots per environmental factor maps in the Brazilian Amazon forest biome (using the 2014 forest mask); detailed legend is above in S2.

\section{Abbreviations}

AGB: aboveground biomass; ALS: airborne laser scanning; CCST: Earth System Science Center; EBA: improving biomass estimation methods for the Amazon, subproject 7 of Remote Sensing Environmental Monitoring of the Amazon Project; Embrapa: Brazilian Agricultural Research Corporation; INPA: National Institute of Amazon Research; INPE: National Institute for Space Research of Brazil; LBA: large-scale biosphere-atmosphere experiment in Amazonia; LiDAR: light detection and ranging; MRV: monitoring and measurement, reporting and verification; NFI: National Forest Inventory; PPBio: The Research Program for Biodiversity; PRODES: Deforestation Monitoring Program; SNA: social network analysis; SL: sustainable landscapes project; RAINFOR: Amazon Forest Inventory Network; REDD+: reducing emissions from deforestation and forest degradation and the role of conservation of forest carbon stocks, sustainable management of forests and enhancement of carbon stocks; TEAM: Tropical Ecology, Assessment, and Monitoring Network; TREES: Tropical Ecosystems and Environmental Sciences Laboratory; UNFCCC: United Nations Framework Convention on Climate Change.

\section{Acknowledgements}

We would like to thank Michael Keller, Marcos Longo and Maiza Nara dosSantos from the SL project for the field and LiDAR data. For the locations of the AGB data, we would like to thank Niro Higuchi, Carlos Celes, Moacir Campos and Adriano Lima from INPA, Luiz Aragão from TREES, Marcus Vinicio Oliveira from Embrapa Acre and Joberto Freitas and Charton Locks from the National Forest Service. For the AGB maps, we thank Sassan Saatchi, Alessandro Baccini, Euler Nogueira, Valerio Avitabile, Edward Mitchard and Pedro Valle. We are grateful to Alex Ovando for his valuable comments on this article. We are also grateful to American Journal Experts for the English revision and to the journal reviewers for their valuable comments.

\section{Authors' contributions}

GT designed the study; undertook the gathering, analysis, and review of the data; and wrote the paper. EBG participated in the study design, conceptualization and refinement and provided a thorough review of the paper. FES refined the study, suggested methods, and improved the writing. RZC helped gather the field and spatial data. JPO provided a thorough review and editing of the paper. All authors read and approved the final manuscript. 


\section{Funding}

This study was supported by the São Paulo Research Foundation (FAPESP) Grant Nos. 2013/20616-6 and 2018/18493-7. We acknowledge the contribution of the project Lidar Remote Sensing of Brazilian Amazon Forests: Analysis of Forest Biomass, Forest Degradation, and Secondary Regrowth funded by the USAID Prime Award Number AID-OAA-A-11-00012. Any opinions, findings, conclusions, or recommendations expressed in such article are those of the authors alone and do not necessarily reflect the views of USAID.

\section{Availability of data and materials}

The datasets supporting the conclusions of this article are included within the article and its Additional file 1.

\section{Ethics approval and consent to participate \\ Not applicable.}

\section{Consent for publication}

Not applicable.

\section{Competing interests}

The authors declare that they have no competing interests.

\section{Author details}

1 Earth System Science Center (CCST), National Institute for Space Research (INPE), Av dos Astronautas 1758, São José dos Campos, SP 12227-010, Brazil. ${ }^{2}$ Department of Forestry Engineering, Universidade Federal dos Vales do Jequitinhonha e Mucuri, Campus JK, Rod. MGT 367, km 583 5000, Alto do Jacuba, Diamantina, MG 39100-000, Brazil. ${ }^{3}$ Centre for Landscape and Climate Research (CLCR) and Leicester Institute for Space and Earth Observation (LISEO), School of Geography, Geology and Environment, University of Leicester, University Road, Leicester LE1 7RH, UK. ${ }^{4}$ United Nations Development Programme (UNDP), SEN 802, 17, Conj. C-St. Mans̃oes DB, Brasília, DF 70800-400, Brazil.

\section{Received: 17 February 2019 Accepted: 20 August 2019}

\section{Published online: 03 September 2019}

\section{References}

1. Ometto JP, Sousa-Neto ER, Tejada G. Land use, land cover and land use change in the Brazilian Amazon (1960-2013). In: Nagy L, Forsberg BR, Artaxo $P$, editors. Interactions between biosphere, atmosphere and human land use in the Amazon Basin. Berlin: Springer; 2016. p. 369-83. https://doi.org/10.1007/978-3-662-49902-3_15.

2. Sousa-Neto ER, Tejada G, Ometto JP. Cenários e Usos da Terra na Amazônia. In: Vieira ICG, de Toledo PM, Junior RAOS, editors. Ambiente e sociedade na Amazônia uma abordagem interdisciplinar. 1st ed. Rio de Janeiro: Garamond; 2014. p. 279-93.

3. Tejada G, Dalla-Nora E, Cordoba D, Lafortezza R, Ovando A, Assis T, et al. Deforestation scenarios for the Bolivian lowlands. Environ Res. 2016;144:49-63. http://linkinghub.elsevier.com/retrieve/pii/S001393511 5301092

4. Fearnside PM. Brazil's Amazonian forest carbon: the key to Southern Amazonia's significance for global climate. Reg Environ Change. 2018;18(1):47-61. https://doi.org/10.1007/s10113-016-1007-2.

5. Aguiar APD, Ometto JP, Nobre C, Lapola DM, Almeida C, Vieira IC, et al. Modeling the spatial and temporal heterogeneity of deforestationdriven carbon emissions: the INPE-EM framework applied to the Brazilian Amazon. Glob Change Biol. 2012;18(11):3346-66. https://doi.org/10.111 1/j.1365-2486.2012.02782.x.

6. MCT. Third national communication of Brazil to the United Nations Framework convention on climate change, Volume III. Ministério da Ciência T e I, editor. Vol. III. Brasília; 2016. p. 333.

7. Romijn E, Herold M, Kooistra L, Murdiyarso D, Verchot L. Assessing capacities of non-Annex I countries for national forest monitoring in the context of REDD+. Environ Sci Policy. 2012;19-20:33-48. https://doi. org/10.1016/j.envsci.2012.01.005.

8. Asner GP, Powell GVN, Mascaro J, Knapp DE, Clark JK, Jacobson J, et al High-resolution forest carbon stocks and emissions in the Amazon. Proc Natl Acad Sci USA. 2010;107(38):16738-42.
9. Benítez FL, Anderson LO, Formaggio AR. Evaluation of geostatistical techniques to estimate the spatial distribution of aboveground biomass in the Amazon rainforest using high-resolution remote sensing data. ACTA Amazon. 2016;46(2):151-60.

10. Longo M, Keller M, Dos-Santos MN, Leitold V, Pinagé ER, Baccini A, et al. Aboveground biomass variability across intact and degraded forests in the Brazilian Amazon. Glo Biogeochem Cycles. 2016:30(11):1639-60.

11. Dos-Santos MN, Keller MM. CMS: forest inventory and biophysical measurements, Para, Brazil, 2012-2014. Tennessee, USA; 2016. http:// dx.doi.org/10.3334/ORNLDAAC/1301.

12. d'Oliveira MVN, Reutebuch SE, McGaughey RJ, Andersen H-E. Estimating forest biomass and identifying low-intensity logging areas using airborne scanning lidar in Antimary State Forest, Acre State, Western Brazilian Amazon. Remote Sens Environ. 2012;124:479-91. https://doi. org/10.1016/j.rse.2012.05.014.

13. UNFCCC. Key decisions relevant for reducing emissions from deforestation and forest degradation in developing countries (REDD+). Framew Conv Clim Chang. 2014;(June):44.

14. MCT. Brazil's initial national communication to the United Nations framework convention on climate change. Brasília; 2004. http://unfcc c.int/essential_background/library/items/3599.php?such=j\&symbo I=BRA/COM/1BCOPY1ENG\#beg.

15. MCT. Second national communication of Brazil to the United Nations framework convention on climate change. Brasília; 2010. http://www. mct.gov.br/index.php/content/view/326984.html.

16. INPE. Amazon deforestation monitoring project (PRODES). Sao Jose dos Campos, SP, Brazil; 2015. http://www.dpi.inpe.br/prodesdigital/ prodes.php.

17. Saatchi S. Consulting study 2: mapping tropical forest biomass: synthesis of ground and remote sensing inventory. Area; 2015.

18. Saatchi SS, Harris NL, Brown S, Lefsky M, Mitchard ETA, Salas W, et al. Benchmark map of forest carbon stocks in tropical regions across three continents. Proc Natl Acad Sci. 2011;108(24):9899-904. https://doi. org/10.1073/pnas.1019576108.

19. Saatchi S, Mascaro J, Xu L, Keller M, Yang Y, Duffy P, et al. Seeing the forest beyond the trees. Glob Ecol Biogeogr. 2015;24(5):606-10. https ://doi.org/10.1111/geb.12256.

20. Mascaro J, Asner GP, Davies S, Dehgan A, Saatchi S. These are the days of lasers in the jungle. Carbon Balance Manag. 2014;9(1):7. https://doi. org/10.1186/s13021-014-0007-0.

21. Palace M, Sullivan FB, Ducey M, Herrick C. Estimating tropical forest structure using a terrestrial lidar. PLoS ONE. 2016;11(4):e0154115. https ://doi.org/10.1371/journal.pone.0154115.

22. Mitchard ETA, Feldpausch TR, Brienen RJW, Lopez-Gonzalez G, Monteagudo A, Baker TR, et al. Markedly divergent estimates of Amazon forest carbon density from ground plots and satellites. Glob Ecol Biogeogr. 2014;23(8):935-46.

23. Ometto JP, Aguiar AP, Assis T, Soler L, Valle P, Tejada G, et al. Amazon forest biomass density maps: tackling the uncertainty in carbon emission estimates. Clim Change. 2014;124(3):545-60.

24. IBGE. Mapa de Biomas do Brasil, primeira aproximação. Rio de Janeiro; 2004. http://mapas.ibge.gov.br/biomas2/viewer.htm.

25. RAINFOR Rede Amazônica de Inventários Florestais. 2015.

26. NFI. Inventário Florestal Nacional_IFN. Inventário Florestal Nacional_ IFN, Serviço Florestal Brasileiro (SFB); 2016. http://ifn.florestal.gov.br/. Accessed 11 Apr 2016

27. Sustainable-Landscapes. Sustainable landscapes; 2016. https://www. paisagenslidar.cnptia.embrapa.br/webgis/.

28. Embrapa. 2016. https://www.embrapa.br/acre. Accessed 1 Apr 2016.

29. INPA, LMF. Laboratório de Manejo Florestal. 2015.

30. TREES. Tropical ecosytems and environmental sciences laboratory (TREES); 2016. http://trees-research.weebly.com/team.html. Accessed 2 Feb 2015.

31. Saatchi SS, Houghton RA, Dos Santos Alvalá RC, Soares JV, Yu Y. Distribution of aboveground live biomass in the Amazon basin. Glob Chang Biol. 2007;13(4):816-37. https://doi.org/10.111 1/j.1365-2486.2007.01323.x.

32. Nogueira EM, Fearnside PM, Nelson BW. Normalization of wood density in biomass estimates of Amazon forests. For Ecol Manag. 2008;256(5):990-6. http://linkinghub.elsevier.com/retrieve/pii/S0378112708004830. 
33. Baccini A, Goetz SJ, Walker WS, Laporte NT, Sun M, Sulla-Menashe D, et al. Estimated carbon dioxide emissions from tropical deforestation improved by carbon-density maps. Nat Clim Change. 2012;2(3):182-5. https://doi. org/10.1038/nclimate1354.

34. Nogueira EM, Yanai AM, Fonseca FOR, Fearnside PM. Carbon stock loss from deforestation through 2013 in Brazilian Amazonia. Glob Change Biol. 2015;21(3):1271-92.

35. Avitabile V, Herold M, Heuvelink GBM, Lewis SL, Phillips OL, Asner GP, et al. An integrated pan-tropical biomass map using multiple reference datasets. Glob Chang Biol. 2016;22(4):1406-20. https://doi.org/10.1111/gcb.13139.

36. Rousseau R, Otte E. Social network analysis: a powerful strategy, also for the information sciences. J Inf Sci. 2002;28(6):441-53. https://doi. org/10.1177/016555150202800601.

37. EBA. EBA-Estimativa de biomassa na Amazônia. Melhoria dos métodos de estimativa de biomassa e de modelos de estimativa de emissões por mudança de uso da terra; 2016. http://www.ccst.inpe.br/projetos/eba-estim ativa-de-biomassa-na-amazonia/. Accessed 6 June 2016.

38. Bernoux M, Volkoff B, Cerri CC. Brazil's soil carbon stocks. Soil Sci Soc Am J. 2002;66(3):888-96. https://dl.sciencesocieties.org/publications/sssaj/abstr acts/66/3/888

39. IBGE. Compartimentos do relevo do Brasil; 2002. http://mapas.mma.gov.br/ i3geo/datadownload.htm

40. IBGE. Mapa de Clima do Brasil. Rio de Janeiro: Diretoria de GeociênciasDGC/Coordenação de Recursos Naturais e Estudos Ambientais-CREN; 2002.

41. RadamBrasil P. Levantamento de Recursos Naturais. Rio de Janeiro-Brazil; 1983

42. TEAM Network. The tropical ecology, assessment and monitoring (TEAM) network. 2016. http://www.teamnetwork.org/. Accessed 18 Apr 2016.

43. Feldpausch TR, Banin L, Phillips OL, Baker TR, Lewis SL, Quesada CA et al. Height-diameter allometry of tropical forest trees. Biogeosciences. 2011:8(5):1081-106. http://www.biogeosciences.net/8/1081/2011/.

44. Oliveira Melo L. Rede de Monitoramento da Dinâmica de Florestas da Amazônia. In: IV Simpósio Nacional de Inventário Florestal. Goiânia; 2016. http://www.florestal.gov.br/arquivos/Apresentacoes_simposio_ pdf/2016 06 30-16h20 Lia Melo.

45. PPBio. Repositório de dados do PPBio; 2012. http://ppbio.inpa.gov.br/repos itorio/dados.

46. Magnusson WE, Lima AP. RAPELD : a modification of the gentry method for biodiversity surveys in long-term ecological research. Biota Neotropica. 2005;5:19-24. https://doi.org/10.1590/S1676-06032005000300002.

47. Malhi Y, Phillips OL, Lloyd J, Baker T, Wright J, Almeida S, et al. An international network to monitor the structure, composition and dynamics of Amazonian forests (RAINFOR). J Veg Sci. 2002;13:439-50. http://eprints.white rose.ac.uk/236/.

48. Higuchi FG, Siqueira JDP, Lima AJN, Figueiredo Filho A, Higuchi N. Influência do Tamanho da Parcela na Precisão da Função de Distribuição Diamétrica de Weibull na Floresta Primária da Amazônia Central. Floresta. 2012;42(3):599. http://revistas.ufpr.br/floresta/article/view/19640.

49. Lima AJN. Avaliaçao de um sistema de inventário florestal contínuo em áreas manejadas e nao manejadas do Estado do Amazonas (AM). Universidade Federal Do Amazonas_-Ufam Instituto Nacional De Pesquisas Da Amazônia_-Inpa Programa Integrado De Pós-Graduação Em Biologia Tropica; 2010

50. McRoberts RE, Tomppo EO, Næsset E. Advances and emerging issues in national forest inventories. Scand J For Res. 2010;25(4):368-81. https://doi. org/10.1080/02827581.2010.496739.

51. Arino O, Perez JR, Kalogirou V, Defourny P, Achard F. Globcover 2009. In: ESA living planet symposium. Bergen, Norway; 2010. p. 1-3.

52. Hansen MC, Potapov PV, Moore R, Hancher M, Turubanova SA, Tyukavina A, et al. High-resolution global maps of 21st-century forest cover change. Science (80-). 2013;342(6160):850-3. https://doi.org/10.1126/science.12446 93.

53. VCS. Guidance on use of VCS tool VT0005; 2015.

54. Dos-Santos MN, Keller MM. CMS: LiDAR data for forested areas in Paragominas, Para, Brazil, 2012-2014. Tennessee, USA: ORNL DAAC; 2016. http:// dx.doi.org/10.3334/ORNLDAAC/1302

55. Tejada G. XI Seminário de Atualização em Sensoriamento Remoto e Sistemas de Informações Geográficas Aplicados à Engenharia Florestal. In: Amazon forest carbon maps, from global IPCC tier 1 to a regional National
Communication of Brazil to the UNFCCC tier 2 approach. Curitiba: IEP; 2014. p. 519-25. http://www.11 sengef.com.br/arquivos/documentos/anaisonlin e/SENGEF2014.pdf.

56. Harris NL, Brown S, Hagen SC, Saatchi SS, Petrova S, Salas W, et al. Baseline map of carbon emissions from deforestation in tropical regions. Science (80-). 2012;336(6088):1573-6. https://doi.org/10.1126/science.1217962.

57. Houghton RA, Lawrence KT, Hackler JL, Brown S. The spatial distribution of forest biomass in the Brazilian Amazon: a comparison of estimates. Glob Chang Biol. 2001;7(7):731-46.

58. Malhi Y, Wood D, Baker TR, Wright J, Phillips OL, Cochrane T, et al. The regional variation of aboveground live biomass in old-growth Amazonian forests. Glob Chang Biol. 2006;12(7):1107-38. https://doi.org/10.111 1/j.1365-2486.2006.01120.x.

59. Quesada CA, Phillips OL, Schwarz M, Czimczik Cl, Baker TR, Patiño S, et al Basin-wide variations in Amazon forest structure and function are mediated by both soils and climate. Biogeosciences. 2012;9(6):2203-46.

60. IBGE. Manual Técnico da Vegetação Brasileira. Instituto Brasileiro de Geografia e Estatística_IBGE. Rio de janeiro, Brasil; 2012. p. 1-271. ftp://geoftp.ibge. gov.br/documentos/recursos_naturais/manuais_tecnicos/manual_tecni co_vegetacao_brasileira.pdf.

61. Nogueira EM, Fearnside PM, Nelson BW, Barbosa RI, Keizer EWH. Estimates of forest biomass in the Brazilian Amazon: new allometric equations and adjustments to biomass from wood-volume inventories. For Ecol Manag. 2008;256(11):1853-67.

62. SIVAM P. Relatório metodológico de trabalho. Revisão 3. Rio de Janeiro; 2002.

63. IBGE. Mapa de Vegetacao do Brasil. Rio de Janeiro; 2004.

64. IBGE. Mapa de Solos do Brasil. Rio de Janeiro; 2001

65. MMA. Programa Zoneamento Ecológico-Econômico; 2006. http://mapas .mma.gov.br/mapas/aplic/zee/atlas_zee_openlayers.htm?1c421f54qsjnqii 3frjqj03vq2.

66. Quesada CA, Lloyd J, Anderson LO, Fyllas NM, Schwarz M, Czimczik CI. Soils of Amazonia with particular reference to the RAINFOR sites. Biogeosciences. 2011;8(6):1415-40

67. IBGE. Censo Agropecuário 2006. Rio de Janeiro: IBGE; 2006.

68. Chave J, Condit R, Aguilar S, Hernandez A, Lao S, Perez R. Error propagation and scaling for tropical forest biomass estimates. Philos Trans R Soc Ser B Biol Sci. 2004;359(1443):409-20. http://www.pubmedcentral.nih.gov/articleren der.fcgi?artid $=1693335 \&$ tool=pmcentrez\&rendertype $=$ abstract.

69. Mapbiomas. Proyecto MapBiomas Amazonía—Colección [1.0] de los mapas anuales de cobertura y uso del suelo; 2019. http://amazonia.mapbiomas. org. Accessed 18 Apr 2019.

70. Le Toan T, Chave J, Dall J, Papathanassiou K, Paillou P, Rechstein M, et al. The biomass mission: objectives and requirements. In: IGARSS 2018-2018 IEEE international geoscience and remote sensing symposium. IEEE; 2018. p. 8563-6. https://ieeexplore.ieee.org/document/8518491/. Accessed 8 Aug 2019 .

71. Mitchard ET, Saatchi SS, Baccini A, Asner GP, Goetz SJ, Harris NL, et al. Uncertainty in the spatial distribution of tropical forest biomass: a comparison of pan-tropical maps. Carbon Balance Manag. 2013;8(1):10. http://www.cbmjo urnal.com/content/8/1/10.

72. Goetz SJ, Baccini A, Laporte NT, Johns T, Walker W, Kellndorfer J, et al. Mapping and monitoring carbon stocks with satellite observations: a comparison of methods. Carbon Balance Manag. 2009;7:1-7.

73. Pan Y, Birdsey RA, Phillips OL, Jackson RB. The structure, distribution, and biomass of the world's forests. Annu Rev Ecol Evol Syst. 2013;44(1):593-622. https://doi.org/10.1146/annurev-ecolsys-110512-135914.

74. IPCC. IPCC guidelines for national greenhouse gas inventories volume-IV agriculture, forestry and other land use. In: Eggleston HS, Buendia L, Miwa K, Ngara T, Tanabe K, editors. 2006 IPCC quidelines for national greenhouse gas inventories. Hayama: Institute for Global Environmental Strategies (IGES); 2006. p. 1-83.

75. RAINFOR. The Amazon forest inventory network (RAINFOR). 2015. http:// www.rainfor.org/. Accessed 3 Mar 2015.

\section{Publisher's Note}

Springer Nature remains neutral with regard to jurisdictional claims in published maps and institutional affiliations. 